Institute of $\mathbf{F}_{\text {ood and }} \mathbf{A}_{\text {gricultural }} \mathbf{S}_{\text {ciences }}$

\title{
2003 Handbook of Employment Regulations Affecting Florida Farm Employers and Workers: Workers' Compensation [State] ${ }^{1}$
}

Leo C. Polopolus, Michael T. Olexa, Fritz Roka, and Carol Fountain ${ }^{2}$

\section{Purpose}

To assure quick and efficient delivery of disability and medical benefits to an injured worker and to facilitate a worker's return to gainful re-employment at a reasonable cost to the employer.

\section{Covered Employers}

All agricultural employers who employ six or more regular employees or employ twelve or more seasonal employees for more than thirty days at one time or forty-five total days in a calendar year.

\section{Covered Employers Must}

Purchase Workers' Compensation insurance by any one of four options:

- Standard policy on open market.

- Individual self insurance.

- Group self insurance.

- Joint underwriting plan of the Florida

Department of Insurance.

\section{Cost of Insurance}

Varies depending on employment activity and experience rating of each employer. (Florida

1. This is EDIS document FE423, a publication of the Department of Food and Resource Economics, Florida Cooperative Extension Service, Institute of Food and Agricultural Sciences, University of Florida, Gainesville, FL. Published July 2003. This information is included in Circular 1200, Handbook of Employment Regulations Affecting Florida Farm Employers and Workers. First published February 1992 as Circular 1043 . Revised December 2002 as Circular 1200. Please visit the EDIS website at http://edis.ifas.ufl.edu.

2. Leo C. Polopolus, Professor Emeritus, Department of Food and Resource Economics, University of Florida, Gainesville, FL; Michael T. Olexa, Professor, Department of Food and Resource Economics, University of Florida, Gainesville, FL; Fritz Roka, Associate Professor, Department of Food and Resource Economics, Southwest Florida Research and Education Center, Immokalee, FL; and Carol Fountain, Assistant Editor, Department of Food and Resource Economics, University of Florida, Gainesville, FL; Florida Cooperative Extension Service, Institute of Food and Agricultural Sciences, University of Florida, Gainesville, FL.

This document is designed to provide accurate, current, and authoritative information on the subject. However, since the laws, administrative rulings, and court decisions on which it is based are subject to constant revision, portions of this publication could become outdated at any time. This publication is distributed with the understanding that the authors are not engaged in rendering legal or other professional advice, and the information contained herein should not be regarded as a substitute for professional advice. For these reasons, the utilization of these materials by any person constitutes an agreement to hold harmless the authors, the Institute of Food and Agricultural Sciences, and the University of Florida for any liability claims, damages, or expenses that may be incurred by any person as a result of reference to or reliance on the information contained in this publication.

The Institute of Food and Agricultural Sciences is an equal opportunity/affirmative action employer authorized to provide research, educational information and other services only to individuals and institutions that function without regard to race, color, sex, age, handicap, or national origin. For information on obtaining other extension publications, contact your county Cooperative Extension Service office. Florida Cooperative Extension Service/Institute of Food and Agricultural Sciences/University of Florida/Christine Taylor Waddill, Dean. 
Department of Insurance approves all Workers' Compensation premium rates for each employment activity and job classification.) Premium rates are defined as percentages of payroll.

\section{Posting Requirement}

\section{Employers not required to have Workers'} Compensation and who do not have coverage must post clear written notice in a conspicuous location at each work site.

\section{Reporting Any Injury}

- Employers, on receiving notice that an employee has been injured, must complete and file a "Notice of Injury Form" (LES Form DWC-1) with the insurance carrier.

- The "Notice of Injury Form" must be in the carrier's hands within seven days from the date that the employer has actual knowledge of accident or injury. A copy of the form shall also be sent to the Florida Division of Workers' Compensation.

- The insurance carrier or self-insured employer must mail Form DWC-1 to the Division of Workers' Compensation in Tallahassee within thirty days of receipt.

- If injury results in death, the employer must give a special notice by telephone or telegraph to the Bureau of Industrial Safety and Health (850) 499-3044 within twenty-four hours. This special notice is not required if the death occurs after the accident has been reported.

\section{Legislative Reform Act Goals}

- Lower costs for employers.

- Slow increase in Workers' Compensation health care costs.

- Create incentives for return to work.

- Reduce number of permanent total disability awards.

- Discourage fraud.
- Promote workplace safety.

- Protect rights of employees to benefits.

\section{Revised Benefits Schedule}

- Total number of weeks an injured worker can receive benefits (excluding permanent total) reduced to 401 weeks from date of accident.

-Wage loss concept was eliminated; but old law still applies to dates of accident before January 1 , 1994.

- Temporary total and temporary partial disability benefits limited to 104 weeks combined.

- Impairment benefits and supplemental benefits replace wage loss benefits (for accidents after January 1, 1994).

- Funeral death benefit increased up to $\$ 5,000$.

\section{For Slowing Increase in Health Care Costs}

- Implementation of managed care: managed care arrangements can be offered by insurer/carrier to employers after April 1, 1994.

- Managed care defined as total management of the health of the injured.

- Managed care arrangements mandatory for all employers after January 1, 1997.

- Insurer/carrier must submit managed care arrangements to Agency for Health Care Administration for approval of plan.

- Premium rate discounts of up to ten percent can be authorized by the Department of Insurance.

\section{Incentives for Return to Work}

- Implementation of managed care: managed care arrangements can be offered by insurer/carrier to employers after April 1, 1994.

- Managed care defined as total management of the health of the injured. 
- Managed care arrangements mandatory for all employers after January 1, 1997.

- Insurer/carrier must submit managed care arrangements to Agency for Health Care Administration for approval of plan.

- Premium rate discounts of up to ten percent can be authorized by the Department of Insurance.

\section{Reduction in Number of Permanent Total Disability Awards}

- To be defined permanent total, the injury must be catastrophic in nature.

- Employers/carriers have the right to conduct vocational evaluations or testing of workers who are permanent total once every calendar year and must give employees seven days notice.

\section{Fraud Discouraged}

- By more clearly defining fraudulent activities.

- By increasing penalties for illegal activities.

- By establishing the Bureau of Workers'

Compensation Hotline at 1(800) 378-0445.

\section{Promoting Workplace Safety}

The Florida Occupational Safety and Health Act contains a provision for a discount in Workers' Compensation premiums for employers who adopt and implement an approved workplace safety program.

\section{Elements of Acceptable Workplace Safety Program}

- Management commitment and involvement.

- Safety committee.

- Safety and health training.

- First aid procedures.

- Accident investigations.

- Record-keeping procedures.
- Safety rules and policies.

\section{Premium Discount for Workplace Safety Program}

Employers who implement safety program approved by the Division of Safety are eligible for premium credits of up to twenty-seven percent.

\section{Protecting Rights of Employees to Benefits}

- Employees Assistance and Ombudsman (E.A.O.) Office created to assist injured workers.

- All disputed issues must go through E.A.O. process before any formal litigation.

- E.A.O. has thirty days after receiving request for assistance to resolve disputes.

- If dispute is resolved at E.A.O. level, no claimant attorney fees are allowed by state statute.

- If dispute is not resolved, E.A.O. will assist unrepresented worker in completing the formal Petition of Benefits.

\section{Drug-Free Workplace Program}

- The purpose of this program is to avoid work-related accidents resulting from drug abuse by employees.

- The Florida Administrative Code for Drug-Free Workplace Standards, as adopted by the Agency for Health Care Administration, shall be utilized for all drug testing pursuant to the Florida Workers' Compensation program.

- Insurance premium discounts of up to five percent are possible for employers having acceptable drug-free workplace programs.

\section{Enforcement}

- The Florida Division of Workers' Compensation can issue Stop Work orders on employers who are required to have coverage and fail to do so. 
- There is a $\$ 100$ per day fine for each day an employer is not in compliance.

\section{Additional Information}

- Chapters 440 and 442, Florida Statutes.

- The Division of Workers' Compensation has a toll-free number that can be used from anywhere in Florida by dialing 1(800) 342-2762, or contact the local area office nearest you.

- Wage Loss and You, Department of Insurance, Division of Workers' Compensation.

- Workers' Compensation and You, Department of Insurance, Division of Workers' Compensation.

- Facts about Workers' Compensation Insurance for Employers, Department of Insurance, Division of Workers' Compensation.

\section{Responsible Agency}

Florida Department of Insurance

Division of Workers' Compensation

200 East Gaines Street

Tallahassee, FL 32399-0300

(850) 413-31001 or

Dial toll-free 1(800) 342-2762

http://www2.myflorida.com/les/wc

http://www2.myflorida.com/les/we/organization/ addresses.html

For local offices, see the telephone directory under

- Florida, State of

- Insurance, Department of

- Workers' Compensation, Division of 